\title{
UJI AKTIVITAS ANTIBAKTERI EKSTRAK RIMPANG KUNYIT HITAM (CURCUMA CAESIA ROXB.)
}

\author{
Desire Janetha Asdedi*, Hanggara Arifian, Laode Rijai \\ Laboratorium Penelitian Pengembangan FARMAKA TROPIS, \\ Fakultas Farmasi, Universitas Mulawarman, Samarinda, Kalimantan Timur \\ *email:desirejanetha@gmail.com
}

\begin{abstract}
ABSTRAK
Rimpang kunyit hitam (Curcuma caesia Roxb.) secara empiris memiliki aktivitas sebagai antibakteri dalam pengobatan herbal. Penelitian ini bertujuan untuk mengetahui aktivitas rimpang kunyit hitam sebagai antibakteri. Oleh karena itu, dilakukan uji pendahuluan aktivitas antibakteri dari ekstrak rimpang kunyit hitam (Curcuma caesia Roxb.). Pengujian antibakteri menggunakan metode difusi agar dengan konsentrasi 15\% 30\%, 40\%, 45\%, 60\%, $75 \%, 80 \%$, dan $100 \%$. Hasil penelitian menunjukkan bahwa ekstrak rimpang kunyit hitam mempunyai daya hambat sebagai antibakteri pada konsentrasi $45 \%$ terhadap Staphylococcus aureus Staphylococcus epidermidis, Escherichia coli, Pseudomonas aeruginosa menghasilkan diameter zona hambat sebesar 7,93 mm , 9,04 mm, 9,12 mm, dan 10,74 mm.
\end{abstract}

Kata kunci : Antibakteri, Curcuma caesia R., Difusi Agar

\begin{abstract}
Black tumeric (Curcuma caesia Roxb.) has been used traditionally to herbal medicine. This study uses black tumeric that have empirical antimicrobial activity. This research is to determine of antibacterial activity is carried out by using agar diffusion methods with eight concentrations were $15 \% 30 \%, 40 \%, 45 \%, 60 \%$, 75\%, 80\%, and 100\%. The results showed that black tumeric rhizome has inhibited test bacterial growth concentration of $45 \%$ against Staphylococcus aureus, Staphylococcus epidermidis, Escherichia coli, Pseudomonas aeruginosa produce diameter of inhibition 7,93 $\mathrm{mm}, 9,04 \mathrm{~mm}, 9,12 \mathrm{~mm}$ and 10,74 $\mathrm{mm}$.
\end{abstract}

Keywords : Antibacterial, Curcuma caesia R., Agar diffusion,

\section{PENDAHULUAN}

Kunyit merupakan salah satu temu-temuan yang sangat sering kita jumpai di sekitar kita. Tumbuhan ini biasanya dijadikan bumbu rempah dan sebagai bahan untuk pembuatan obat-obatan khususnya untuk obat tradisional. Ada tiga jenis kunyit yang kita kenal di Indonesia yaitu kunyit kuning, kunyit putih dan kunyit hitam. Kunyit hitam (Curcuma caesia Roxb.) merupakan varian baru yang muncul sebagai pendatang baru dalam pengobatan herbal terutama di negara India, Pakistan dan Turki. Di Indonesia, kunyit hitam (Curcuma caesia Roxb.) berasal dari spesies curcuma yang masih kurang dikenal (Sudewo, 2012).

Kunyit hitam (Curcuma caesia Roxb.) memiliki potensi sebagai tumbuhan berkhasiat obat karena mengandung senyawa-senyawa bioaktif seperti flavonoid, fenol dan 
alkaloid (Fong, 2012, Sarangthem dkk, 2010). Senyawa-senyawa bioaktif ini memiliki sifat antibakteri. Beberapa penelitian terdahulu telah membuktikan adanya daya antibakteri beberapa bagian tumbuhan kunyit hitam (Curcuma caesia Roxb.) (Chatoopadhyay, dkk, 2004). Pada penelitian ini, bagian tumbuhan kunyit hitam (Curcuma caesia Roxb.) yang akan diuji daya antibakterinya adalah rimpang. Ekstrak rimpang kunyit hitam (Curcuma caesia Roxb.) akan diuji aktivitasnya dengan menggunakan bakteri Staphylococcus aureus, Staphylococcus epidermidis. Escherichia coli, dan Pseudomonas aeruginosa. Oleh karena itu, perlu dilakukan pengujian lebih lanjut aktivitas antibakteri yang terkandung dalam rimpang kunyit hitam (Curcuma caesia Roxb.) berdasarkan letak geografisnya dan menambah informasi ilmiah.

\section{ALAT DAN BAHAN}

Alat-alat yang digunakan dalam penelitian ini adalah hot plate (Stuart SD160), inkubator (Froilabo), mikrometer sekrup (Boeco Germany), jarum ose, laminar air flow (Froilabo NU-126-400E), mikropipet 10-100 $\mu$ l (Boeco Germany), tip mikropipet ukuran 10-100 $\mu \mathrm{L}$ (Eppendorff), microplate (Biohit Proline), otoklaf (Tomy SX-700), oven (Froilabo), pembakar spiritus, dan timbangan analitik (Precisa XB220A).

Bahan tumbuhan yang digunakan dalam penelitian ini adalah rimpang kunyit hitam yang berasal dari perkarangan rumah warga di Kecamatan Makale, Kabupaten Tana Toraja, Sulawesi Selatan.

Bahan kimia yang digunakan adalah metanol 70\% (PT. Dover Chem), DMSO/dimetilsulfooksida (Merck), suspensi Mc. Farland 0,5 (9,5 mL asam sulfat $1 \% \mathrm{~b} / \mathrm{v}$ dan $0,5 \mathrm{~mL}$ barium klorida $1 \% \mathrm{v} / \mathrm{v}), \mathrm{NaCl} 0,9 \%$ dan air suling.

Biakan bakteri yang digunakan adalah Staphylococcus aureus Staphylococcus epidermidis, Escherichia coli, Pseudomonas aeruginosa yang berasal dari Laboratorium Mikrobiologi Farmasi, Fakultas Farmasi, Universitas Mulawarman. Medium pertumbuhan atau medium uji yang digunakan adalah NA/Nutrient Agar (Oxoid, Basingstoke, UK).

\section{METODE PENELITIAN \\ Pengambilan Sampel}

Tumbuhan yang digunakan pada penelitian ini adalah rimpang kunyit hitam yang berasal dari perkarangan rumah warga di Kecamatan Makale, Kabupaten Tana Toraja, Sulawesi Selatan. Bagian tumbuhan yang digunakan adalah bagian rimpang yang masih segar. Sampel yang telah terkumpul dicuci bersih selanjutnya dilakukan sortasi basah. Pengeringan dilakukan untuk mengurangi kadar air dengan cara dianginkan. Selanjutnya disortasi kering untuk memilih sampel yang telah kering bebas dari kotoran dan kerusakan. Setelah itu dilakukan perajangan untuk memperluas permukaan rimpang kunyit hitam.

\section{Prosedur Ekstraksi}

Simplisia dimasukkan ke dalam bejana maserasi dan dimaserasi menggunakan pelarut metanol. Proses ekstraksi dengan metode maserasi berlangsung selama kurang lebih 3 hari. Maserat (hasil maserasi) disaring menggunakan kertas saring dan ditampung ke dalam wadah. Maserat kemudian dipekatkan menggunakan rotary evaporator dan dilanjutkan dengan penguapan diatas waterbath hingga diperoleh ekstrak metanol kental. 


\section{Prosedur Pengujian}

\section{Pengujian Metabolit Sekunder}

Identifikasi metabolit sekunder ekstrak rimpang kunyit hitam dilakukan menggunakan ekstrak metanol dengan cara mengamati perubahan warna dan terjadi pengendapan reagen kimia.Golongan metabolit sekunder yang diuji adalah steroid, saponin, flavonoid, tanin, fenol, dan alkaloid. Metabolit sekunder ekstrak rimpang kunyit hitam dianalisis dengan cara tabulasi jika terdapat metabolit sekunder setelah penambahan reagen kimia tertentu diberi tanda positif (+) dan jika tidak terdapat metabolit sekunder diberi tanda negatif (-).

\section{Pengujian Aktivitas Antibakteri}

Pengujian aktivitas antibakteri terhadap Staphylococcus aureus Staphylococcus epidermidis, Escherichia coli, Pseudomonas aeruginosa dilakukan dengan metode difusi agar dengan tahapan kerja meliputi :

\section{a. Pembuatan Medium}

Medium Nutrien Agar (NA) dibuat dengan cara melarutkan 5 g NA ke dalam 250 $\mathrm{mL}$ air, suling kemudian dipanaskan hingga larut. Sebanyak $5 \mathrm{~mL}$ NA cair dituang ke dalam tabung reaksi, lalu dan dimiringkan $45^{\circ}$ sehingga membentuk agar miring.

\section{b. Sterilisasi Alat dan Medium}

Alat dan medium yang akan digunakan disterilisasi dalam otoklaf selama 15 menit pada suhu $121^{\circ} \mathrm{C}$.

\section{c. Penyiapan Suspensi Bakteri Uji}

Bakteri uji Staphylococcus aureus Staphylococcus epidermidis, Escherichia coli, Pseudomonas aeruginosa ditanamkan di atas permukaan NA miring, lalu diinkubasikan selama 18-24 jam pada suhu $37^{\circ} \mathrm{C}$. Kekeruhan supensi disesuaikan dengan suspensi standar Mc. Farland 0,5, sehingga suspensi bakteri tersebut mengandung $10^{4} \mathrm{CFU} / \mathrm{mL}$.

\section{d. Uji Aktivitas Antibakteri}

Sebanyak $10 \mu \mathrm{L}$ suspensi bakteri uji dimasukkan ke dalam cawan petri steril, lalu ditambahkan $10 \mathrm{~mL}$ NA yang masih cair. Cawan digoyang-goyangkan supaya bakteri dan NA tercampur secara homogen, lalu dibiarkan hingga memadat.

Sebanyak $10 \mathrm{~g}$ dilarutkan dalam $10 \mathrm{~mL}$, sehingga diperoleh konsentrasi 15\% 30\%, $40 \%, 45 \%, 60 \%, 75 \%, 80 \%$, dan 100\%. Masing-masing konsentrasi dan aquades (kontrol pelarut) ditaruh pada medium dengan cara dicelupkan. Cawan petri diinkubasi selama 24 jam pada suhu $37^{\circ} \mathrm{C}$ di inkubator. Diameter zona hambat yang terbentuk diukur menggunakan mikrometer sekrup.

\section{HASIL DAN PEMBAHASAN}

\section{Metabolit Sekunder Ekstrak Rimpang Kunyit Hitam}

Ekstrak rimpang kunyit hitam dilarutkan dengan metanol, karena sifat pelarutnya mudah untuk melarutkan semua komponen-komponen senyawa bioaktif seperti flavonoid, fenol dan alkaloid. Senyawa-senyawa bioaktif ini memiliki sifat sebagai antibakteri.

Golongan metabolit sekunder yang diuji pada ekstrak rimpang kunyit hitam yaitu steroid, saponin, flavonoid, tanin, fenol, dan alkaloid. Hasil identifikasi golongan metabolit sekunder ekstrak rimpang kunyit hitam dapat dilihat pada Gambar 1. 

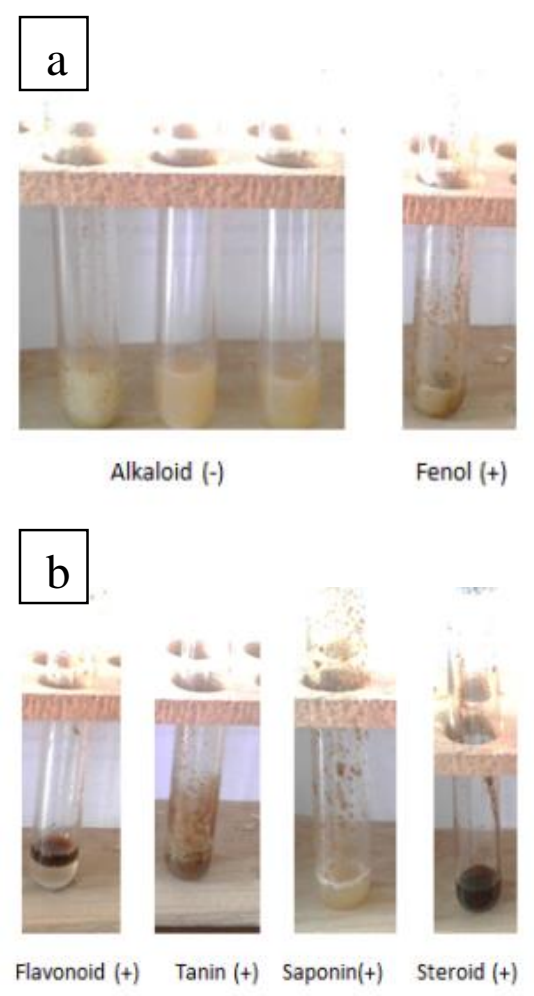

Gambar 1. Identifikasi metabolit sekunder ekstrak rimpang kunyit hitam

Keterangan : Ekstrak rimpang kunyit hitam terhadap metabolit sekunder (a) alkaloid dan fenol, (b) flavonoid, tanin, saponin dan steroid.

Terlihat pula perbedaan masing-masing golongan metabolit sekunder yang diuji, dimana ekstrak rimpang kunyit hitam pada golongan senyawa alkaloid memberikan hasil negatif tidak mengandung golongan senyawa sedangkan pada golongan senyawa steroid, saponin, flavonoid, tanin, dan fenol memberikan hasil positif mengandung golongan senyawa. Hal ini membuktikan bahwa zat aktif yang terkandung dalam tumbuhan tersebut adalah steroid, flavonoid, fenol, saponin dan tanin. Data yang menunjukkan hasil identifikasi metabolit sekunder ekstrak rimpang kunyit hitam dapat dilihat pada tabel berikut ini :

Tabel 1. Identifikasi Metabolit Sekunder Rimpang Kunyit Hitam

\begin{tabular}{cc}
\hline Metabolit & Perlakuan \\
\cline { 2 - 2 } Sekunder & Ekstrak Metanol \\
\hline Steroid & + \\
Saponin & + \\
Flavonoid & + \\
Tanin & + \\
Fenol & + \\
Alkaloid & - \\
\hline
\end{tabular}

Keterangan :

Data berupa data kualitatif (-) dan (+), dimana:

(-): Tidak teridentifikasi metabolit sekunder

(+): Teridentifikasi metabolit sekunder 
Berdasarkan hasil identifikasi metabolit sekunder pada Tabel di atas menunjukkan bahwa uji flavonoid menunjukkan teridentifikasi senyawa flavonoid pada ekstrak metanol rimpang kunyit hitam yang ditunjukkan dengan terbentuknya warna merah. Uji saponin pada ekstrak metanol rimpang kunyit hitam menunjukkan bahwa senyawa saponin teridentifikasi dengan ditunjukkan terjadi pembentukan buih yang stabil pada saat ekstrak dikocok dan didiamkan 15 menit (setelah itu ditambahkan $\mathrm{HCl}$ ). uji tanin menunjukkan teridentifikasi senyawa tanin pada ekstrak metanol rimpang kunyit hitam dengan terbentuknya warna hitam kehijauan. Uji steroid menunjukkan teridentifikasi senyawa golongan steroid yaitu triterpenoid pada ekstrak metanol rimpang kunyit hitam yang ditunjukkan dengan terbentuknya larutan berwarna merah keunguan. Uji fenol menunjukkan teridentifikasi senyawa fenol pada ekstrak metanol rimpang kunyit hitam yang ditunjukkan dengan terbentuknya warna merah. Uji alkaloid tidak teridentifikasi metabolit sekunder dengan membentuk warna jingga atau endapan putih.

\section{Aktivitas Antibakteri Ekstrak Rimpang Kunyit Hitam}
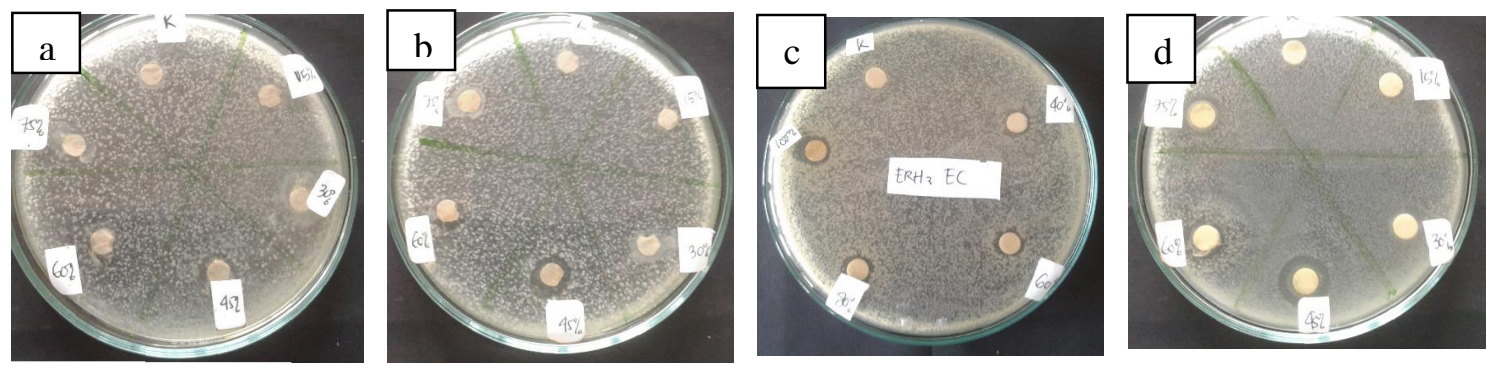

Gambar 2. Uji aktivitas antibakteri ekstrak rimpang kunyit hitam terhadap bakteri (a) Staphylococcus aureus, (b) Staphylococcus epidermidis, (c) Escherichia coli, (d) Pseudomonas aeruginosa.

Pengujian aktivitas antibakteri ekstrak rimpang kunyit hitam dilakukan dengan menggunakan berbagai tingkat konsentrasi. Konsentrasi yang digunakan 15\%, 30\%, 40\%, 45\%, 60\%, 75\%, 80\% dan 100\% untuk bakteri Staphylococcus aureus, Staphylococcus epidermidis, Escherichia coli dan Pseudomonas aeruginosa. Hasil pengujian aktivitas antibakteri ekstrak rimpang kunyit hitam dapat dilihat pada Gambar 2.

Hasil uji akitivitas antibakteri dengan konsentrasi 15\%, 30\%, 40\%, 45\%, 60\%, 75\%, $80 \%$ dan 100\% terhadap Staphylococcus aureus, Staphylococcus epidermidis, Escherichia coli dan Pseudomonas aeruginosa menghasilkan diameter zona hambat sebesar 7,93 $\mathrm{mm}$, 9,04 mm, 9,12 mm, dan 10,74 mm pada konsentrasi 45\% disekitar paperdisc yang terlihat pada Gambar 2. Pada kontrol negatifnya (aquades) tidak terbentuk zona hambat disekitar paperdisc sehingga disimpulkan bahwa pelarut yang digunakan tidak mempengaruhi aktivitas antibakteri dari sampel uji, hal ini membuktikan bahwa aktivitas antibakteri merupakan aktivitas dari ekstrak rimpang kunyit hitam.

Terlihat pula adanya perbedaan aktivitas pada masing-masing bakteri uji, dimana bakteri Staphylococcus aureus pada konsentrasi $40 \%$ dan $80 \%$ tidak terbentuk zona hambat disekitar paperdisc. Staphylococcus epidermidis pada konsentrasi 15\%, 30\%, 40\%, 60\%, 75\%, $80 \%$ dan 100\% tidak terbentuk zona hambat disekitar paper disc. Escherichia coli pada konsentrasi $40 \%$ dan $80 \%$ tidak terbentuk zona hambat disekitar paperdisc. Pseudomonas aeruginosa pada konsentrasi 15\%, 30\%, 40\%, 80\% dan 100\% tidak terbentuk zona hambat disekitar paper disc sedangkan pada bakteri uji Staphylococcus aureus, 
Staphylococcus epidermidis, Escherichia coli dan Pseudomonas aeruginosa pada konsentrasi $45 \%$ terbentuk zona hambat disekitar paperdisc. Data yang menunjukkan zona hambat yang terbentuk dari aktivitas ekstrak rimpang kunyit hitam dirangkumkan pada Tabel 1.

Tabel 2. Zona hambat yang terbentuk dari hasil aktivitas ekstrak rimpang kunyit hitam.

\begin{tabular}{|c|c|c|c|}
\hline Sampel Uji & Bakteri Uji & Konsentrasi & $\begin{array}{l}\text { Diameter Zona Hambat } \\
(\mathrm{mm})\end{array}$ \\
\hline Ekstrak & S.a & $15 \%$ & 0 \\
\hline Rimpang Kunyit & $(+)$ & $30 \%$ & 0 \\
\hline \multirow[t]{30}{*}{ Hitam } & & $40 \%$ & 0 \\
\hline & & $45 \%$ & 7,93 \\
\hline & & $60 \%$ & 11,83 \\
\hline & & $75 \%$ & 9,85 \\
\hline & & $80 \%$ & 0 \\
\hline & & $100 \%$ & 8,45 \\
\hline & S.e & $15 \%$ & 0 \\
\hline & $(+)$ & $30 \%$ & 0 \\
\hline & & $40 \%$ & 0 \\
\hline & & $45 \%$ & 9,04 \\
\hline & & $60 \%$ & 0 \\
\hline & & $75 \%$ & 0 \\
\hline & & $80 \%$ & 0 \\
\hline & & $100 \%$ & 0 \\
\hline & E.c & $15 \%$ & 0 \\
\hline & $(-)$ & $30 \%$ & 0 \\
\hline & & $40 \%$ & 0 \\
\hline & & $45 \%$ & 9,12 \\
\hline & & $60 \%$ & 8,32 \\
\hline & & $75 \%$ & 6,03 \\
\hline & & $80 \%$ & 0 \\
\hline & & $100 \%$ & 10,13 \\
\hline & P. $a$ & $15 \%$ & 0 \\
\hline & $(-)$ & $30 \%$ & 0 \\
\hline & & $40 \%$ & 0 \\
\hline & & $45 \%$ & 10,74 \\
\hline & & $60 \%$ & 8,64 \\
\hline & & $75 \%$ & 7,22 \\
\hline & & $80 \%$ & - \\
\hline & & $100 \%$ & - \\
\hline \multicolumn{2}{|c|}{$\begin{array}{c}\text { Kontrol Negatif } \\
\text { (Aquadest) }\end{array}$} & - & 0 \\
\hline
\end{tabular}

Keterangan : Staphylococcus aureus (S.a), Staphylococcus epidermidis (S.e), Escherichia coli (E.c) dan Pseudomonas aeruginosa (P.a).

Tabel 2 dan Gambar 2 menunjukkan bahwa semakin meningkat konsentrasi sampel uji maka semakin besar pula zona hambat yang terbentuk. Terlihat pada ekstrak rimpang kunyit hitam dengan konsentrasi $40 \%$, dan $80 \%$ tidak dapat menghambat pertumbuhan bakteri Staphylococcus aureus dan Escherichia coli tetapi pada konsentrasi 15\%, 30\%, 45\%, 
60\%, 75\%, dan 100\% tidak dapat menghambat pertumbuhan bakteri Escherichia coli dan Staphylococcus aureus sedangkan pada ekstrak rimpang kunyit hitam dengan konsentrasi $60 \%$ dan $75 \%$ tidak dapat menghambat pertumbuhan bakteri Staphylococcus epidermidis tetapi dapat menghambat pertumbuhan bakteri Pseudomonas aeruginosa.

Pada data diameter zona hambat yang terbentuk juga menunjukkan bahwa ekstrak rimpang kunyit hitam lebih efektif pada Gram negatif daripada Gram positif. Perbedaan aktivitas antibakteri dari masing-masing bakteri uji pada ekstrak rimpang kunyit hitam diduga karena adanya perbedaan struktur dinding sel bakteri pada keempat jenis bakteri tersebut.

Dinding sel bakteri Gram positif terdiri atas beberapa lapisan peptidoglikan yang membentuk struktur yang tebal dan kaku serta mengandung substansi dinding sel yang disebut asam teikoat, sedangkan dinding sel bakteri Gram negatif terdiri atas satu atau lebih lapisan peptidoglikan yang tipis dan membran dibagian luar lapisan peptidoglikan. Karena hanya mengandung sedikit lapisan peptidoglikan dan tidak mengandung asam teikoat, maka dinding sel bakteri Gram negatif lebih rentan terhadap guncangan fisik, seperti pemberian antibiotik atau bahan bakteri lainnya. Hasil uji aktivitas yang dilakukan tersebut, ekstrak rimpang kunyit hitam berpotensi atau memiliki aktivitas sebagai antibakteri.

\section{KESIMPULAN}

Berdasarkan penelitian yang telah dilakukan, diperoleh kesimpulan bahwa

1. Kandungan metabolit sekunder yang terdapat di dalam ekstrak rimpang kunyit hitam adalah senyawa golongan ekstrak steroid, saponin, flavonoid, tanin, dan fenol.

2. Ekstrak rimpang kunyit hitam berpotensi mempunyai aktivitas antibakteri terhadap Staphylococcus aureus, Staphylococcus epidermidis, Escherichia coli dan Pseudomonas aeruginosa.

\section{DAFTAR PUSTAKA}

Fong, Y. M. 2012. In Vitro Regeneration of Kunyit Hitam (Curcuma caesia Roxb.). Faculty of Resource Science \& Technology. Universitas Malaysia Serawak, Hal 3-6

Kaliappan, N. 2008. Fitokimia. UI Press: Jakarta

Sudewo, B., 2012. Basmi Kanker dengan Herbal. Transmedia. Jakarta, Hal 38-40

Zuraida, A. R., 2013. Improved in Vitro Propagation of Curcuma caesia, a Valuable Medicinal Plant. J. Trop. Agic. and Fd. Sc. Vol. 41 Hal. 2 